\title{
Britain since 1939
}

Progress and Decline 


\title{
British Studies Series
}

\author{
General Editor: JEREMY BLACK
}

\section{Published}

T. A. Jenkins

The Liberal Ascendancy, 1830-1886

David Childs

Britain since 1939: Progress and Decline

\section{Forthcoming}

C. J. Bartlett

High Politics and Grand Strategy: Britain and the World since

Glenn Burgess John Charmley 1945

W. H. Fraser

Brian Hill

British Political Thought from Reformation to Revolution

J. P. Kenyon

British Conservatism in the Twentieth Century

The Rise and Fall of British Trade Unionism

British Parties since 1688

David Loades

Britain, 1689-1714

Diarmaid MacCulloch

Power in Sixteenth-Century Britain

Allan MacInnes

The Reformation in Britain, 1480-1680

Alexander Murdoch

The British Revolution

W. Rubinstein

Andrew Thorpe

British History, 1660-1832

History of Britain in the Twentieth Century

$A$ History of the Labour Party 


\title{
Britain since 1939 Progress and Decline
}

\author{
David Childs
}


(C) David Childs 1995

Softcover reprint of the hardcover 1st edition 1995

All rights reserved. No reproduction, copy or transmission of this publication may be made without written permission.

No paragraph of this publication may be reproduced, copied or transmitted save with written permission or in accordance with the provisions of the Copyright, Designs and Patents Act 1988, or under the terms of any licence permitting limited copying issued by the Copyright Licensing Agency, 90 Tottenham Court Road, London WIP 9HE.

Any person who does any unauthorised act in relation to this publication may be liable to criminal prosecution and civil claims for damages.

First published 1995 by MACMILLAN PRESS LTD

Houndmills, Basingstoke, Hampshire RG21 2XS

and London

Companies and representatives

throughout the world

ISBN 978-0-333-48681-8

ISBN 978-1-349-23967-2 (eBook)

DOI 10.1007/978-1-349-23967-2

A catalogue record for this book is available from the British Library

$\begin{array}{rrrrrrrrrr}10 & 9 & 8 & 7 & 6 & 5 & 4 & 3 & 2 & 1\end{array}$

$\begin{array}{llllllllll}04 & 03 & 02 & 01 & 00 & 99 & 98 & 97 & 96 & 95\end{array}$

Typeset by Acorn Bookwork, Salisbury, Wiltshire 


\section{Contents}

Acknowledgements $\quad$ xi

Introduction xiii

1 Interwar Britain, 1919-39 1

Impact of the 'Great War' 1

Media Changes 2

Monarchy 4

Lloyd George, Baldwin and MacDonald 5

The 'General Strike' $\quad 7$

MacDonald's Second Administration $\quad 7$

National Government $\quad 9$

Law and Order 11

High Street Changes 12

'This blot on our national life' 12

Unemployment and Industrial Activity 14

$\begin{array}{ll}\text { Right and Left } & 15\end{array}$

Election $1935 \quad 17$

A More Secular Society 18

$\begin{array}{ll}\text { A Moderate Conservative Consensus } & 19\end{array}$

2 Britain and the World, 1919-39 23

Palestine, India and the Empire 23

Anglo-Irish Relations 25

Chamberlain and Appeasement 28

Britain and Japan $\quad 30$

Britain and the USA 31

Munich and Beyond $\quad 33$

Public Opinion $\quad 34$

3 Britain at War, 1939-41 37

The Left and the War 37

Norway Overrun $\quad 39$

Churchill's Government $\quad 40$ 
The Fall of France $\quad 41$

British Territory Captured 43

Hitler's Call 'to Reason' Rejected 44

Eire's 'Emergency' $\quad 46$

Detained $\quad 47$

Battle of Britain $\quad 49$

Defeats in Greece and North Africa $\quad 50$

4 From European War to World War and Victory, 1941-45

'A marvellous morning' 53

Waiting for Uncle Sam $\quad 54$

'Quit India' 55

'beastly little monkeys' $\quad 57$

'Token Payment' Needed 58

Beveridge's Report $\quad 59$

Women at War $\quad 60$

'an absolutely, devastating, exterminating attack' 61

El Alamein and Operation Torch 64

Battle of the Atlantic $\quad 65$

D-Day $\quad 66$

The Nazis Defeated $\quad 67$

Yalta and Potsdam $\quad 68$

Labour's Victory $\quad 69$

Japan Surrenders $\quad 71$

5 Britain under Attlee, 1945-51 74

Attlee's Colleagues $\quad 74$

American Loan $\quad 75$

Taking the Commanding Heights $\quad 76$

British Raj Ends $\quad 76$

Guerrilla Warfare in Palestine $\quad 78$

Bevan and the National Health Service 81

Republic of Ireland $\quad 82$

Cold War $\quad 84$

Britain's Bomb $\quad 86$

Counter Insurgency in Malaya $\quad 87$

Economic Progress $\quad 88$

British Society $\quad 90$

London Olympics $\quad 94$ 
'migrants of good human stock . . ' 96

Election $1950 \quad 96$

War in Korea $\quad 98$

Labour in Turmoil 100

6 From Churchill to Macmillan, 1951-60 104

Election $1955 \quad 105$

Elizabeth II 106

Economic Progress and Decline 108

Conflict over Capital Punishment 109

Suez $\quad 110$

Missing the Bus for Europe 113

Independent Television $\quad 115$

Colonial Retreat $\quad 116$

Cyprus Emergency 119

'Bricks for Empire Building' 119

Gaitskell and Bevan 120

Election 1959 . 122

7 Conservatives on the Run, 1961-64 125

Education 125

Cultural Revolution $\quad 127$

Heart Searching on Immigration 130

Labour's Revival 132

'Not British, not independent and not a deterrent' 133

'The Cult of Amateurishness' 134

Ireland: De Valera Departs 135

Home Replaces Macmillan 137

Wilson's Victory 139

8 Harold Wilson at the Helm, 1964-70 141

Sterling Crisis 141

Department of Economic Affairs $\quad 142$

Ice Cold Atmosphere 145

Aviation Crisis $\quad 145$

Defence: 'Over-commitment' 146

'a parliamentary leper' 147

Rhodesia, Vietnam and East of Suez 148

Conservatives Elect Heath 150

Election $1966 \quad 151$ 
Wilson's Summer Cuts 152

Devaluation: '. . . the pound in your pocket' 154

Swinging London 155

Education Reform and Welfare 157

Trouble in Northern Ireland 158

Powell, 'We must be mad . . ' $\quad 159$

1970 Surprise Defeat 161

9 Trouble and Strife, 1970-74 164

EEC Membership 164

Industrial Relations 166

Ireland: Embarrassment in the South $\quad 167$

Ireland: Unrest in the North 169

$\begin{array}{ll}\text { Uganda Asians } & 170\end{array}$

Liberal Revival $\quad 171$

Oil Crisis and Miners' Strike $\quad 173$

Heath Out, Wilson In 174

'a kind of archaism of the society and national $\begin{array}{ll}\text { psychology' } 175 & 175\end{array}$

10 Trouble and Strife, 1974-79 177

Election October $1974 \quad 177$

$\begin{array}{ll}\text { Anti-terrorism } & 179\end{array}$

National Enterprise $\quad 179$

$\begin{array}{ll}\text { Irish Cauldron } & 181\end{array}$

'. . . she has never looked prettier' 182

EEC: 'Parliament should take that decision . . ' 182

Silver Jubilee $\quad 183$

Sex Discrimination $\quad 185$

Wilson: 'sagacity and sangfroid' 185

'. . people of different cultures' 187

Ireland in Transition $\quad 188$

The Social Contract and Industrial Democracy 190

Lib-Lab Agreement 192

Conservative Victory 193

11 The Thatcher Era, 1979-87 196

The Road to Serfdom 196

Labour Elects Foot 198

The Social Democrats 200 
Riots on a Summer Day 201

War with Argentina 202

Hong Kong, Southern Africa 204

Thatcher Returned 205

Labour's New Leader, Neil Kinnock 207

Industrial Relations and the Miners 207

A Bomb in Brighton $\quad 209$

Privatisation $\quad 210$

Defence Problems $\quad 212$

Tory Revolts 213

Election $1987 \quad 214$

12 Thatcher in Decline, 1987-90 217

SDP Ends in 'Loveless Meetings' 217

Stock Exchange's 'Black Monday' 218

The Rise and Fall of the Poll Tax 219

From New Brutalism to Post-Modernism 220

Welfare 'safe with us' 221

Education in the 1980s 222

Main Churches Face Decline 224

Irish Parties in the 1980s 226

The Conservatives and the EC 227

Major Replaces Thatcher $\quad 230$

13 Major's Avalanche of Problems 232

Conflict in the Gulf 232

Trouble with Law and Order 233

Maastricht 235

Royal Troubles $\quad 236$

Election $1992 \quad 238$

Women in Parliament . . . and Elsewhere 239

Why did Labour Lose? 241

Media under Attack $\quad 242$

Major under Pressure $\quad 245$

$\begin{array}{ll}\text { Postscript } & 248\end{array}$

14 Britain and Ireland in the 1990s 249

Unity Only 'peacefully and without coercion' 249

Changing Ireland 250

Whither Britain? 252 
Economic Decline

'class system is still there ...'

Legacies of Empire

\section{Appendix}

A.1 Key British ministers since 1918

A.2 Leaders of parties in all governments of Irish Free State/Eire/Irish Republic since the general election of 27 August 1923

A.3 British general elections, 1918-92

A.4 Women elected to parliament in the UK and Germany at selected elections

A.5 Expectation of life, at birth, by sex in the UK

A.6 Population of the United Kingdom, in thousands

A.7 Distribution of shareholding between categories of owner, 1963-89, in percentages

A.8 Average gross domestic product per capita, in 1993, in the European Union, according to purchasing power, average $=100$ 


\section{Acknowledgements}

In a way, I started interviewing for this book when I had a long conversation with Lord (Clement) Attlee in 1963. Since then, I have been privileged to meet many other public figures who, to a greater or lesser degree, have helped to shape Britain since 1918. Apart from the Rt Hon. Kenneth Clarke, PC, MP, I have not attempted to re-interview those I met in connection with my other contributions on recent British history. I remain indebted to them and to those who, more recently, agreed to be interviewed, or to answer my written enquiries: Rt Hon. Lord Callaghan, KG; Rt Hon. Tony Benn, MP; Field-Marshal Lord Carver, MC; Mrs Edwina Currie, MP; Stefan Lorant, founder of Picture Post, Bill Newton Dunn, MEP for Lincolnshire; Martin Groves, Office of the Houses of the Oireachtais, Dublin; Rt Hon. Neil Kinnock, MP; Rt Hon. Lord Longford, KG; Rt Hon. Lord Parkinson; Professor Alan Watson, CBE, former President of the Liberal Party. I am once again in debt to my old friend Dr Robert L. Frazier, formerly of the History Department of Nottingham University, who read an earlier version of the manuscript and made many valuable suggestions for improvements. Finally, I would like to thank Kate Craine, MA, for her help in preparing the final draft of the manuscript. I must, of course, emphasise that I alone am responsible for the views expressed in the book, as well as for any errors of fact or judgement.

Nottingham

DAVID CHILDS 


\section{Introduction}

The title of the book is Britain since 1939: Progress and Decline, but I felt I would have produced an incomprehensible account if I had started in the year war broke out, decisive though the Second World War was for Britain's subsequent political, social and economic development. I decided, therefore, to write two introductory chapters covering the interwar period.

This book is about the general developments in British politics and society, but there is an underlying theme which is difficult to ignore - that is, the decline of Britain since the 'Great War' of 1914-18. And although the book attempts to tell the story in chronological order, using the different political administrations as convenient, recognisable signposts, this underlying theme is discussed, implicitly or explicitly, throughout. Some will argue that, although Britain has declined in economic terms, it has not done so in other respects; in particular, its institutions have adapted and survived better than those of most European states. To a degree, they are right. In addition, great progress can be seen, in the arts and sciences, standards of living and people's opportunities. Yet the decline in the economy means that Britain is less able to support the things its citizens want and need - better education and training, better health care, better transport systems, better law enforcement, and defence forces adequate to our commitments. In one or all of these areas, many European, and some non-European, states have caught up with, or overtaken, Britain. It is baffling that a nation with so much talent at its disposal has decayed so much, right down to the 1990s. I have done my best to provide some clues to that puzzle, but I do not claim to have a definitive answer. As another recent writer admitted, at the end of his study of Britain's decline, 'Our understanding of Britain's relative failure ... remains incomplete and unsatisfactory.*

Britain has also made great progress during the same period, and this cannot be ignored if one wishes to understand the political development of the country. However, in attempting to document both our progress

*Michael Dintenfass, The Decline of Industrial Britain, 1870-1980 (London, 1992). 
and decline, I have invited the student and the general reader alike to pause and think about particular incidents and general themes - education, colonialism, immigration and racism, crime, the media, the monarchy, popular opinion, the changing role of women, etc. - in the history of the period. These are often neglected in a general book of this relatively modest size. I hope I have covered the main events in a fairly objective way so that readers who do not agree with some of my assessments, nevertheless find the book useful.

Originally I had no intention of writing about Ireland, except to cover, briefly, events leading up to the treaty of 1921, and some more recent events in Northern Ireland. However, I found it difficult to discuss these without, at least, glancing in the direction of Dublin. The more I looked, the more I got involved. I do not regret this. Considering our histories and populations are so intertwined, Ireland is all too often a far-away country of which we know little. I hope my references to the South will be seen merely as an aid to British readers who do not normally consider Ireland as part of their studies or interest. My hope is that they will then move on to more substantial accounts. It has not been my ambition to compete with the excellent Irish and British writers who cover Irish history at greater depth. Nor.is it my intention to imply that Ireland is in any sense part of the United Kingdom - on the contrary, I believe Irish independence was a positive development. 